\title{
Seroprevalence of HBV and HCV markers among young adult males in the Air Force in Florianópolis, South Brazil
}

\author{
Ana Maria Passos ${ }^{1}$, Miguel Strazer Neto ${ }^{2}$, Aricio Treitinger ${ }^{1}$, Celso Spada ${ }^{1, *}$ \\ ${ }^{1}$ Clinical Analysis Department, Health Sciences Center, Federal University of Santa Catarina, Florianópolis, Santa Catarina, \\ Brazil; ${ }^{2}$ Hospital of Federal University of Santa Catarina, Florianópolis, Santa Catarina
}

\begin{abstract}
We investigated the prevalence of hepatitis $\mathrm{B}$ virus (HBV) and hepatitis $\mathrm{C}$ virus (HCV) serological markers of infection in young adults from the metropolitan region of Florianópolis who were conscripts of the Air Base of Florianópolis in the state of Santa Catarina, Brazil. A population-based cross-sectional seroprevalence study was conducted with 371 young males during a one year period starting in June 2009. Demographic characteristics, socio-economic characteristics and possible risk factors to HBV and HCV were assessed. Blood samples were analyzed for HBsAg, anti-HBc, anti-HCV and anti-HBs through automated microparticle enzymatic immunoassays (Abbott ${ }^{\circledR}$, AxSYM System, Wiesbaden, Germany). None of the participants showed positivity to HBsAg or anti-HCV. The prevalence of anti-HBc was $1.6 \%$ (95\% CI $0.6-3.5)$, and the prevalence of anti-HBs was $40.7 \%$ (95\% CI $35.7-45.9)$. Unsafe sex was associated with positive anti-HBc in a bivariate analysis. There was a very low prevalence of past HBV infection and no cases of past HCV infection in a young adult population in the metropolitan region of Florianópolis. The very low prevalence of markers of infection and risk factors indicates a very optimistic future with respect to $\mathrm{HBV}$ and $\mathrm{HCV}$ infection in this population.
\end{abstract}

Uniterms: HBV. HCV. Hepatitis B. Hepatitis C. Seroprevalence.

Este estudo teve como objetivo investigar a prevalência dos marcadores sorológicos de infecção pelo HBV e HCV em adultos jovens na Região Metropolitana de Florianópolis, conscritos da Base Aérea de Florianópolis, Santa Catarina, Brasil. Trata-se de um estudo soroepidemiológico transversal de base populacional com 371 adultos jovens, no período de um ano a partir de junho de 2009. Foram pesquisadas características sócio-econômicas e possíveis fatores de risco para HBV e HCV. As amostras de sangue foram analisadas quanto à presença de $\mathrm{HBsAg}$, anti-HBc, anti-HCV e anti-HBs pelo método imunoensaio enzimático automatizado de micropartículas (Abbott ${ }^{\circledR}$, Sistema AxSYM, Wiesbaden, Alemanha). Nenhum dos participantes demonstrou positividade para HBsAg ou anti-HCV. A prevalência do anti-HBc foi de 1,6\% (IC 95\% 0,6 - 3,5) e do anti-HBs foi 40,7\% (IC 95\% 35,7 - 45,9). Relação sexual desprotegida associou-se com a positividade do anti-HBc na análise bivariada. Demonstrou-se prevalência muito baixa de infecção passada pelo HBV e ausência de HCV nesta população de adultos jovens na Região Metropolitana de Florianópolis. A particularidade desta prevalência muito baixa de marcadores de infecção e fatores de risco aponta para um quadro otimista em relação ao HBV e HCV no futuro para esta população.

Unitermos: HBV. HCV. Hepatite B. Hepatite C. Soroprevalência.

\section{INTRODUCTION}

Infections with hepatitis B virus (HBV) and hepatitis $\mathrm{C}$ virus (HCV) are still major public health problems and

Correspondence: C. Spada. Departamento de Análises Clínicas, Centro de Ciências da Saúde, Univerisade Federal de Santa Catarina, 88040-900 - Florianópolis - SC, Brazil. E-mail: celso@ccs.ufsc.br represent significant causes of morbidity and mortality worldwide. Despite the recent development of vaccines and pharmacological treatment alternatives, such infections increase the risk of hepatic decompensation, cirrhosis and hepatocellular carcinoma (WHO, 2002).

The World Health Organization (2009) estimates that, currently, more than two billion people worldwide have been infected with HBV, and of these people, ap- 
proximately 360 million are chronically infected. For $\mathrm{HCV}$, estimates indicate that 3 to 4 million people are infected annually and that there are 170 million chronic carriers worldwide (WHO, 1999).

In Brazil, a recent partnership between the Ministry of Health, through the National Program of Viral Hepatitis, the Municipal and State Health Secretariats and the federal universities has resulted in the Brazilian National Survey of Viral Hepatitis project, which is currently in its final stage. The project is investigating the true picture of the disease in the country by investigating the population from 10 to 69 years old in 27 Brazilian cities (Ximenes et al., 2010). Nevertheless, there are still few studies that address the general population.

In Brazil, the wide territory and cultural and economic differences influence the unequal distribution of hepatitis B and C throughout the country (MS, 2008).

Additionally, prevalence studies of $\mathrm{HBV}$ and $\mathrm{HCV}$ markers in South Brazil, more specifically in the state of Santa Catarina, are scarce. Although a recent study has determined such prevalences in 10- to 16-year-old students in the metropolitan region of Florianópolis (MRF), the prevalences of $\mathrm{HBV}$ and $\mathrm{HCV}$ in the population born prior to the HBV vaccine implementation in the state remain unknown.

Hepatitis B vaccination began in 1989 in some regions of Brazil and was primarily directed to specific groups. Some years later (1998), it became available in more regions and to both children aged below 1 year and high-risk populations. Afterwards, the coverage of the vaccine was extended to students in health-related fields, military personnel and adolescents up to 15 years old. Specifically in Santa Catarina, the vaccination was recommended to children aged below 4 years in 1993, and this recommendation increased to include children up to 15 years old in 1996. In 2001, the National Immunization Program was extended to the population up to 19 years old (MS, 2003).

Because awareness of the epidemiologic profile and risk factors in the population is crucial for establishing and evaluating health political programs, there is an urgent need to determine these profiles.

Therefore, the aim of this study was to investigate the prevalence of HBV and HCV serological markers in young adults of the MRF, who were conscripts of the Air Base of Florianópolis in the state of Santa Catarina, Brazil.

\section{PATIENTS AND METHODS}

This population-based cross-sectional seroprevalence study included young males, who were residents of the MRF and conscripts of the Brazilian Air Force at the Air Base of Florianópolis, during a 1-year period beginning in June 2009. Military service is mandatory in Brazil, and every male must enroll for service at the selection commission in the year he turns 18, regardless of schooling and socio-economic level. Each commission is responsible for assessing the conscripts residing in the given region, based on the number of inhabitants of the location.

All conscripts were invited to participate in the study upon their arrival at the air base, before any evaluation or test, to minimize selection bias.

A total of 371 individuals ( $90.5 \%$ of all conscripts) consented to participate in the study, and this sample was considered to be sufficient to determine a prevalence of $\mathrm{HBV}$ and $\mathrm{HCV}$ markers from 0 to $40 \%$ with a $95 \%$ confidence interval (CI) and 0.05 alpha error (Motta, Wagner, 2003).

Approval for the study was obtained from the Ethics Committee of the Federal University of Santa Catarina (protocol 136/2009), and all subjects were enrolled after providing written informed consent.

A self-administered standard questionnaire, adapted from one that was previously established and tested (Ximenes et al., 2010), was administered to each subject to identify socio-demographic characteristics (age, ethnicity, marital status, education level of the subjects and their parents, residency, occupation and family monthly income) and possible $\mathrm{HBV}$ - and $\mathrm{HCV}$-related risk factors (history of hepatitis for the subjects and their families, hospitalization, blood transfusion, tattoos or piercings, intravenous drug use, unsafe sex, men who have sex with men and history of sexually transmitted diseases).

Following the questionnaire, blood samples were obtained from all enrolled subjects and stored at $-20^{\circ} \mathrm{C}$ until transportation to the Laboratory of Clinical Analysis of the University Hospital of the Federal University of Santa Catarina.

Serology comprised HBsAg, anti-HBc, anti-HBs and anti-HCV, and every test was performed using automated microparticle enzymatic immunoassays (Abbott ${ }^{\circledR}$, AxSYM System, Wiesbaden, Germany). HBsAg, anti$\mathrm{HBc}$ and anti-HCV results were categorized as "positive" or "negative" according to the provided cut-offs, and antiHBs titers were categorized as "undetectable" (anti-HBs $<10 \mathrm{mIU} / \mathrm{mL}$ ) and "reactive" (anti-HBs $\geq 10 \mathrm{mIU} / \mathrm{mL}$ ), according to the manufacturer's instructions. Samples with positive or borderline results for any marker of infection were retested, and all remaining borderline and indeterminate results were tested using automated chemiluminescent magnetic microparticle immunoassay (Abbott $\AA$, ARCHITECT System, Wiesbaden, Germany). 
Positive cases were referred to the nearest health care center to perform confirmatory tests and receive further counseling and monitoring.

Descriptive statistics consisted of the characterization of the studied population (socio-demographic characteristics) and the assessment of HBV and HCV risk factors through the respective percentages and median and standard deviation (SD) for continuous variables.

The bivariate analysis consisted of Pearson's Chisquare test to compare categorical values, with a significance level of $P<0.050$. For the multivariate analysis, non-conditional logistic regression was used to identify associations between participant socio-demographic characteristics, possible risk factors and anti-HBc status. This model included variables that were significant at $P<0.200$ in Pearson's Chi-square test. All reported values are twotailed. The dependent variable was anti-HBc status, and the independent variables were residency, family monthly income and unsafe sex.

Results are presented as the odds ratio (OR) and the respective $95 \% \mathrm{CI}$ and $P$ value. Unadjusted OR (UOR) refers to univariate logistic regression analysis, and adjusted OR (AOR) refers to multivariate logistic regression analysis.

All data were entered into and analyzed using SPSS version 11.0 (SPSS Inc., Chicago, IL, USA).

\section{RESULTS}

The majority of the participants were 18 years old (80\%), white (71\%) and single (85\%) (Table I). Most were attending or had completed high school (92\%) and lived in the capital city of Florianópolis (64\%).

TABLE I - Demographic and socio-economic characteristics of young adults in South Brazil by anti-HBc status

\begin{tabular}{|c|c|c|c|c|c|c|c|}
\hline \multirow{3}{*}{ Variable } & \multicolumn{4}{|c|}{ Anti-HBc } & \multirow{3}{*}{$P$} & \multirow{2}{*}{\multicolumn{2}{|c|}{ Total }} \\
\hline & \multicolumn{2}{|c|}{ Positive } & \multicolumn{2}{|c|}{ Negative } & & & \\
\hline & $\mathrm{n}$ & $\%$ & $\mathrm{n}$ & $\%$ & & $\mathrm{n}$ & $\%$ \\
\hline Total & 6 & 1.6 & 364 & 98.4 & & 371 & 100.0 \\
\hline \multicolumn{8}{|l|}{ Age (years old) ${ }^{\mathrm{a}}$} \\
\hline 18 & 4 & 1.3 & 293 & 98.7 & 0.408 & 297 & 80.1 \\
\hline 19 & 2 & 2.7 & 72 & 97.3 & & 74 & 19.9 \\
\hline \multicolumn{8}{|l|}{ Ethnicity } \\
\hline White & 5 & 1.9 & 260 & 98.1 & 0.515 & 265 & 71.4 \\
\hline Brown/Black & 1 & 0.9 & 105 & 99.1 & & 106 & 28.6 \\
\hline \multicolumn{8}{|l|}{ Marital status } \\
\hline Married/in a relationship & 1 & 1.8 & 56 & 98.2 & 0.929 & 57 & 15.4 \\
\hline Single/no relationship & 5 & 1.6 & 309 & 98.4 & & 314 & 84.6 \\
\hline \multicolumn{8}{|l|}{ Education } \\
\hline$\leq$ Elementary school & 1 & 3.4 & 28 & 96.6 & 0.606 & 29 & 7.8 \\
\hline$<$ High school & 1 & 0.9 & 111 & 99.1 & & 112 & 30.2 \\
\hline$\geq$ High school & 4 & 1.7 & 226 & 98.3 & & 230 & 62.0 \\
\hline \multicolumn{8}{|l|}{ Parents' education } \\
\hline$\leq$ Elementary school & 3 & 2.2 & 134 & 97.8 & 0.517 & 137 & 36.9 \\
\hline$\leq$ High school & 3 & 1.7 & 169 & 98.3 & & 172 & 46.4 \\
\hline$>$ High school & 0 & 0.0 & 62 & 100.0 & & 62 & 16.7 \\
\hline \multicolumn{8}{|l|}{ Residency } \\
\hline Capital city of Florianópolis & 2 & 0.8 & 235 & 99.2 & 0.116 & 237 & 63.9 \\
\hline Other cities of the MRF & 4 & 3.0 & 130 & 97.0 & & 134 & 36.1 \\
\hline \multicolumn{8}{|l|}{ Employed } \\
\hline Yes & 4 & 2.0 & 199 & 98.0 & 0.553 & 203 & 54.7 \\
\hline No & 2 & 1.2 & 166 & 98.8 & & 168 & 45.3 \\
\hline \multicolumn{8}{|l|}{ Familiar monthly income $\mathrm{e}^{\mathrm{b}}$} \\
\hline $1-4$ & 2 & 0.9 & 217 & 99.1 & 0.197 & 219 & 59.0 \\
\hline 5 or more & 4 & 2.6 & 148 & 97.4 & & 152 & 41.0 \\
\hline
\end{tabular}

a Mean and median age $-18 \pm 0.5$ (95\% CI 18.2-18.3).

${ }^{\mathrm{b}}$ Brazilian minimum wage $-\mathrm{R} \$ 510.00$ (approximately US\$ 300.00) 
None of the participants showed positivity to HBsAg or anti-HCV. The prevalence of anti-HBc in the studied population was $1.6 \%(95 \%$ CI $0.6-3.5)$ and of anti-HBs was $40.7 \%$ (95\% CI $35.7-45.9)$. Four of the six positive anti-HBc subjects were anti-HBs reactive.

Table II shows the results of the HBV possible risk factors assessment. Unsafe sex was significantly associated with positive anti-HBc $(P=0.040)$.

Age, ethnicity, marital status, education, parents' education, occupation, history of hepatitis for the subjects and their families, hospitalization, blood transfusion, tat- toos or piercings, intravenous drug use, men who have sex with men and history of sexually transmitted diseases were not significantly associated with anti-HBc $(P>0.2)$ in the bivariate analysis.

The association between unsafe sex and anti-HBc [UOR $7.2(0.8-62.3)]$ in the logistic regression analysis was inconclusive $(P=0.077)$ (Table III).

Residency [AOR $3.6(0.6-20.1)$ ], family monthly income [AOR 2.6 (0.5-14.8)] and unsafe sex [AOR 6.7 $(0.8-58.4)]$ had no statistically significant association with anti-HBc in the multivariate regression model.

TABLE II - Possible risk factors related to HBV infection in young adults in South Brazil by anti-HBc status

\begin{tabular}{|c|c|c|c|c|c|c|c|}
\hline \multirow{3}{*}{ Variable } & \multicolumn{4}{|c|}{ Anti-HBc } & \multirow{3}{*}{$P$} & \multirow{2}{*}{\multicolumn{2}{|c|}{ Total }} \\
\hline & \multicolumn{2}{|c|}{ Positive } & \multicolumn{2}{|c|}{ Negative } & & & \\
\hline & $\mathrm{n}$ & $\%$ & $\mathrm{n}$ & $\%$ & & $\mathrm{n}$ & $\%$ \\
\hline Total & 6 & 1.6 & 364 & 98.4 & & 371 & 100.0 \\
\hline \multicolumn{8}{|c|}{ History of hepatitis } \\
\hline Yes & 0 & 0.0 & 5 & 100.0 & 0.955 & 5 & 1.3 \\
\hline No & 5 & 1.6 & 305 & 98.4 & & 310 & 83.6 \\
\hline Unknown & 1 & 1.8 & 55 & 98.2 & & 56 & 15.1 \\
\hline \multicolumn{8}{|c|}{ Family history of hepatitis } \\
\hline Yes & 6 & 1.8 & 324 & 98.2 & 0.384 & 41 & 11.1 \\
\hline No & 0 & 0.0 & 41 & 100.0 & & 330 & 88.9 \\
\hline \multicolumn{8}{|c|}{ Hospitalization } \\
\hline Yes & 3 & 2.7 & 110 & 97.3 & 0.294 & 113 & 30.5 \\
\hline No & 3 & 1.2 & 255 & 98.8 & & 258 & 69.5 \\
\hline \multicolumn{8}{|c|}{ Blood transfusion } \\
\hline Yes & 0 & 0.0 & 5 & 100.0 & 0.810 & 5 & 1.3 \\
\hline No & 6 & 1.7 & 341 & 98.3 & & 347 & 93.6 \\
\hline Unknown & 0 & 0.0 & 19 & 100.0 & & 19 & 5.1 \\
\hline \multicolumn{8}{|c|}{ Piercings or tattoos } \\
\hline Yes & 2 & 2.0 & 96 & 98.0 & 0.698 & 98 & 26.4 \\
\hline No & 4 & 1.5 & 269 & 98.5 & & 273 & 73.6 \\
\hline \multicolumn{8}{|c|}{ Intravenous drug use } \\
\hline Yes & 0 & 0.0 & 5 & 100.0 & 0.773 & 5 & 1.3 \\
\hline No & 6 & 1.6 & 360 & 98.4 & & 366 & 98.7 \\
\hline \multicolumn{8}{|l|}{ Unsafe sex } \\
\hline Yes & 5 & 3.2 & 152 & 96.8 & 0.040 & 157 & 42.3 \\
\hline No & 1 & 0.5 & 213 & 99.5 & & 214 & 57.7 \\
\hline \multicolumn{8}{|c|}{ Men who have sex with men } \\
\hline Yes & 0 & 0.0 & 1 & 100.0 & 0.898 & 1 & 0.3 \\
\hline No & 6 & 1.6 & 364 & 98.4 & & 370 & 99.7 \\
\hline \multicolumn{8}{|c|}{ History of sexually transmitted diseases } \\
\hline Yes & 0 & 0.0 & 1 & 100.0 & 0.898 & 1 & 0.3 \\
\hline No & 6 & 1.6 & 364 & 98.4 & & 370 & 99.7 \\
\hline
\end{tabular}


TABLE III - Multivariate non-conditional logistic regression analysis between variables significant at $P<0.2$ in bivariate analysis and anti-HBc status

\begin{tabular}{|c|c|c|c|c|c|}
\hline & $\begin{array}{c}\text { Anti-HBc rate \% } \\
(\mathrm{n} / \mathrm{N})\end{array}$ & $\begin{array}{c}\text { UOR } \\
(95 \% \mathrm{CI}) \\
\end{array}$ & $P$ & $\begin{array}{c}\mathrm{AOR} \\
(95 \% \mathrm{CI})\end{array}$ & $P$ \\
\hline \multicolumn{6}{|l|}{ Residency } \\
\hline Florianópolis & $0.8(2 / 237)$ & 1 & 0.141 & 1 & 0.149 \\
\hline MRF & $3.0(4 / 134)$ & $3.6(0.7-20.0)$ & & $3.6(0.6-20.1)$ & \\
\hline \multicolumn{6}{|l|}{ FMI } \\
\hline $1-4$ & $0.9(2 / 219)$ & 1 & 0.218 & 1 & 0.275 \\
\hline 5 or more & $2.6(4 / 152)$ & $2.9(0.5-16.0)$ & & $2.6(0.5-14.8)$ & \\
\hline \multicolumn{6}{|l|}{ Unsafe sex } \\
\hline Yes & $3.2(5 / 157)$ & $7.0(0.8-60.6)$ & 0.077 & $6.7(0.8-58.4)$ & 0.086 \\
\hline No & $0.5(1 / 214)$ & 1 & & 1 & \\
\hline
\end{tabular}

FMI, family monthly income

\section{DISCUSSION}

The main findings of this study were the low prevalence of HBV serological markers of infection in young males who were born prior to the implementation of the vaccination against hepatitis $B$ in this region, which is highly comparable to that of children and adolescents in the same region, from 10- to 16-year-old with a high immunization rate $(90 \%)$, (HBsAg $(0 \%)$ and anti-HBc [0.5\% (95\%CI $0.1-1.9)]$ ) (Voigt et al., 2010).

In accord with the National Health and Nutritional examination survey, anti-HBc positivity alone indicates past contact with the virus, and the negative HBsAg in all cases demonstrates that the virus had already been cleared from the organism (McQuillan et al., 1999). Although only two of the six anti-HBc positive individuals had reactive anti-HBs, the anti-HBs titers may have waned through the years, becoming undetectable despite past contact with the virus (Zanetti et al., 2005; Hammitt et al., 2007; But et al., 2008). Alternatively, these four cases may represent false positive cases, the "window phase" of an acute HBV infection or an unresolved chronic HBV infection with low grade, possibly intermittent virus production and detectable serum or liver HBV-DNA (Knoll et al., 2006).

The anti-HBc prevalence found in our study is also very similar to the prevalence found by the Brazilian National Survey of Viral Hepatitis in the investigation of viral hepatitis in the northeast region, the central region and the federal district from 2004 to 2005 among 13- to 19-yearold non-vaccinated $(3.5 \%, 2.2 \%$ and $1.6 \%$, respectively) and vaccinated $(1.3 \%, 1.5 \%$ and $1.3 \%$, respectively) individuals (Pereira et al., 2009).

Additionally, this prevalence is also similar to the rate found in adolescents with immunization rates up to
$98 \%$ in the state $(1.4 \%$ and $0.6 \%)$ (Scaraveli et al., 2011; Tonial et al., 2011), the rate reported in Portugal for adolescents with a mean age of 14 years old $(0.6 \%)$ (Antunes, Macedo, Estrada, 2004), and the rate reported in Italy for individuals up to 24 years old (1.0\%) (Fabris et al., 2008); however, it is inferior to the rate reported by Nascimento et al. (2008) in first-time eligible blood-donors from north, northeast and southeast Brazil (2.9\%) and to the rate found in blood donors in south Brazil (15.6\%) (Martelli et al., 1999) and the MRF (4.5\%) (Rosini et al., 2003).

These low prevalences found in this study may reflect low HBV circulation among subjects in young adulthood, probably due to the recent vaccination efforts (2001) in infants and adolescents up to 20 years old in Brazil, the success of which is supported by the anti-HBs prevalence rate found in this study. This rate, although lower, is similar to the rate in Greece $(62.2 \%)$ in 17 - to 34-year-olds (German et al., 2006) and higher than the rate in the USA (31.5\%) in 18- to 35-year-olds (Scott et al., 2005); both studies utilized military recruits and took place 10 years after mandatory hepatitis B immunization was established. As previously mentioned, anti-HBs titers may have decreased over the years, thus suggesting that many more than $40.7 \%$ of the subjects may be immunized.

Analysis of these data allows one to observe a further reduction in anti-HBc seroprevalence among adults in South Brazil during the last decade. Additionally, when compared to seropositivity for HBsAg of $2.6 \%$ among 1,006 Brazilian Army conscripts in 2002 (Toledo et al., 2005), our results document a significant reduction in HBsAg seroprevalence, reinforcing the observation that the HBV seroprevalence has significantly decreased after the establishment of hepatitis B vaccination.

Although low rates of $\mathrm{HBV}$ infection are expected 
in infants and adolescents as a consequence of high immunization rates, low virus circulation and little exposure to risk factors based on the young age, young adults aged 18 and 19 years are expected to be exposed to a wide range of risk behaviors.

In the analysis of possible risk factors, unsafe sex was significantly associated with anti-HBc in the bivariate analysis, in agreement with other seroepidemiological studies. This finding reinforces the importance of safe sex and education to safe sexual behavior as a powerful prevention tool.

Unlike other studies, we did not find significant associations between anti-HBc and some well-documented risk factors, such as tattoos, piercings, sexually transmitted diseases and intravenous drug use. However, the absence of such associations may be due to the low prevalence of anti-HBc, resulting in wide $95 \%$ CIs and ORs; thus, the presence of moderate associations should not be ruled out.

Regarding the absence of positive anti-HCV found in the present study, although this absence represents a good perspective regarding hepatitis $\mathrm{C}$ infection in the future for this population, this result was not surprising based on the most common modes of HCV transmission and the age of the studied population. Other studies carried out in Brazil found zero prevalence (Voigt et al., 2009) and very low anti-HCV prevalence, similar to studies carried out in developed countries such as England and Wales (0.61\%) (Balogun et al., 2002).

We acknowledge that there are some limitations to our analysis. Certain caution is necessary when extrapolating these findings to the target population, although our findings were fairly similar to other studies within the country and, more specifically, within this same region. Additionally, because the answers about risk factors were collected by self-administered questionnaires that included questions regarding illicit and "inadequate" habits, such results may have been underestimated.

Despite the above limitations, the results of this study point to the continuous progress toward the eradication of HBV transmission in south Brazil through universal immunization, with special attention given to the "catch up" immunization of non-vaccinated adolescents. This "catch up" immunization may have played a key role in guarantying the current low infection rates in these South Brazilian young adults who were born two or three years before the implementation of hepatitis $B$ vaccination in this state, in agreement with the cohort effect of successfully immunizing infants and adolescents suggested by Koya, Hill, Darden (2008). This trend allows us to foresee a progressive continuous decrease in HBV circulation, which may lead to a fully immunized population followed by a consequently decrease in hospitalization and treatment expenses regarding HBV and thus a possible redirection of public health funds to treat less preventable diseases. Accordingly, this change in the HBV scenario may occur faster and more effectively if all adults are successfully immunized, which suggests a need to re-evaluate current vaccination strategies to determine whether to include a wider age range that includes adults and to formulate strategies to guarantee infant and adolescent vaccination through mandatory policies, which have been proven to be effective in other countries.

This study demonstrated, for the first time, the hepatitis $\mathrm{B}$ and $\mathrm{C}$ profile of a young adult population in the MRF, South Brazil. This population was born prior to the establishment of the hepatitis $\mathrm{B}$ vaccination in this region and has distinct characteristics in comparison to the general adult Brazilian population, based on the very low anti-HBc prevalence of markers of infection and risks factors. This profile, which is very similar to that of developed countries where hepatitis $B$ vaccination has been fully and successfully implemented, indicates a very optimistic situation with respect to the HBV and $\mathrm{HCV}$ infection rate in the future for this population. Furthermore, it highlights the effectiveness of the National Immunization Program Protocol for hepatitis B and the great importance of maintaining education and awareness campaigns for disease prevention through safe sexual behavior, among others. Further investigation should examine the vaccination coverage and immunity in this population and provide more data to guide the needed changes in the current immunization policies.

\section{ACKNOWLEDGEMENTS}

The present study was supported by the National Council for Scientific and Technological Development $\mathrm{CNPq}-$ Brazil.

The authors would like to thank the Air Base of Florianópolis and the Hemocenter and the Laboratory of the University Hospital of the Federal University of Santa Catarina for their support.

\section{REFERENCES}

ANTUNES, H.; MACEDO, M.; ESTRADA, A. Taxa de cobertura vacinal com imunização para o vírus da hepatite B. Acta Med. Port., v.17, p.303-308, 2004. 
BALOGUN, M.A.; RAMSAY, M.E.; HESKETH, L.M.; ANDREWS, N.; OSBORNE, K.P.; GAY, N.J.; MORGANCAPNER, P. The prevalence of hepatitis $\mathrm{C}$ in England and Wales. J. Infect., v.45, p.219-226, 2002.

BUT, D.Y.; LAI, C.L.; LIM, W.L.; FUNG, J.; WONG, D.K.; YUEN, M.F. Twenty-two years follow-up of a prospective randomized trial of hepatitis $B$ vaccines without booster dose in children: final report. Vaccine, v.26, p.6587-6591, 2008

FABRIS, P.; BALDO, V.; BALDOVIN, T. BELLOTTO, E.; RASSU, M.; TRIVELLO, R.; TRAMARIN, A.; TOSITTI, G.; FLOREANI, A. Changing Epidemiology of HCV and HBV Infections in Northern Italy: A Survey in the General Population. J. Clin. Gastroenterol., v.42, p.527-532, 2008.

GERMAN, V.; GIANNAKOS, G.; KOPTERIDES, P.; LIASKONIS, K.; FALAGAS, M.E. Serologic indices of hepatitis B virus infection in military recruits in Greece (2004-2005). BMC Infect. Dis., v.6, p.163, 2006.

HAMMITT, L.L; HENNESSY, T.W.; FIORE, A.E.; ZANIS, C.; HUMMEL, K.B.; DUNAWAY, E.; BULKOW, L.; MCMAHON, B.J. Hepatitis B immunity in children vaccinated with recombinant hepatitis $B$ vaccine beginning at birth: a follow-up study at 15 years. Vaccine, v.25, p.69586964, 2007.

KNOLL, A.; HARTMANN, A.; HAMOSHI, H.; WEISLMAIER, K.; JILG, W. Serological pattern "anti-HBc alone": characterization of 552 individuals and clinical significance. World J. Gastroenterol., v.28, p.1255-1260, 2006.

KOYA, D.L.; HILL, E.G.; DARDEN, P.M. The effect of vaccinated children on increased hepatitis $\mathrm{B}$ immunization among high-risk adults. Am. J. Public Health, v.98, p.832838, 2008.

MARTELLI, C.M.; TURCHI, M.; SOUTO, F.J.; SAEZALQUEZAR, A.; ANDRADE, A.L.; ZICKER, F. Anti$\mathrm{HBc}$ testing for blood donations in areas with intermediate hepatitis B endemicity. Rev. Panam. Salud Publica, v.6, p.69-73, 1999.

MCQUILLAN, G.M.; COLEMAN, P.J.; KRUSZON-MORAN, D.; MOYER, L.A.; LAMBERT, S.B.; MARGOLIS, H.S. Prevalence of hepatitis B virus infection in the United States: the National Health and Nutrition Examination Surveys, 1976 through 1994. Am. J. Public Health, v.89, p.14-18, 1999.
MINISTÉRIO DA SAÚDE. Hepatites virais: O Brasil está atento. 3.ed. Brasília, DF: Ministério da Saúde, 2008. 60p.

MINISTÉRIO DA SAÚDE. Programa nacional de imunizações: PNI 30 anos. Brasília, DF: Fundação Nacional de Saúde, 2003. 208p.

MOTTA, V.T.; WAGNER, M.B. Bioestatística. Caxias do Sul: Educs; São Paulo: Robe Editorial, 2003. 201p.

NASCIMENTO, M.C.; MAYAUD, P.; SABINO, E.C.; TORRES, K.L., FRANCESCHI, S. Prevalence of hepatitis B and C serological markers among first-time blood donors in Brazil: a multi-center serosurvey. J. Med. Virol., v.80, p.53-57, 2008.

PEREIRA, L.M.M.B.; MARTELLI, C.M.T.; MERCHÁNHAMANN, E.; MONTARROYOS, U.R.; BRAGA, M.C.; LIMA, M.L.C.; CARDOSO, M.R.A.; TURCHI, M.D.; COSTA, M.A.; ALENCAR, L.C.A.; MOREIRA, R.C.; FIGUEIREDO, G.M.; XIMENES, R.A.A. Populationbased multicentric survey of hepatitis B infection and risk factor differences among three regions in Brazil. Am. J. Trop. Med. Hyg., v.81, p.240-247, 2009.

ROSINI, N.; MOUSSE, D.; SPADA, C.; TREITINGER, A. Seroprevelence of $\mathrm{HbsAg}$, anti-HBc and anti-HCV in Southern Brazil, 1999-2001. Braz. J. Infect. Dis., v.7, p.262-267, 2003.

SCARAVELI, N.G.; PASSOS, A.M.; VOIGT, A.R.; LIVRAMENTO, A.; TONIAL, G.; TREITINGER, A.; SPADA, C. Seroprevalence of hepatitis B and hepatitis $\mathrm{C}$ markers in adolescents in Southern Brazil. Cad. Saúde Pública, v.27, p.753-758, 2011.

SCOTT, P.T.; NIEBUHR, D.W.; MCGREADY, J.B.; GAYDOS, J.C. Hepatitis B immunity in United States military recruits. J. Infect. Dis., v.191, p.1835-1841, 2005.

TOLEDO, A.C.; GRECO, D.B.; FELGA, M.; BARREIRA, D.; GADELHA, M.D.E.; SPERANZA, F.A. Seroprevalence of hepatitis B and C in Brazilian army conscripts in 2002: a cross-sectional study. Braz. J. Infect. Dis., v.9, p.374-383, 2005.

TONIAL, G.; PASSOS, A.M.; LIVRAMENTO, A.; SCARAVELI, N.G.; BATSCHAUER, A.P.B.; BUENO, E.C.; LARGURA, A.; SPADA, C.; TREITINGER, A. Hepatitis B marker seroprevalence and vaccination coverage in adolescents in the City of Itajaí, State of Santa Catarina, Southern Brazil, in 2008. Rev. Soc. Bras. Med. Trop., v.44, p.416-419, 2011. 
VOIGT, A.R.; STRAZER NETO, M.; SPADA, C.; TREITINGER, A. Seroprevalence of hepatitis B and hepatitis $\mathrm{C}$ markers amon children and adolescentes in the South Brazilian Region - Metropolitan Area of Florianópolis, Santa Catarina. Braz. J. Infect. Dis., v.14, p.60-65, 2010.

WORLD HEALTH ORGANIZATION. Global distribution of hepatitis A, B and C, 2001. Wkly. Epidemiol. Rec., v.77, p.46-47, 2002.

WORLD HEALTH ORGANIZATION. Hepatitis B vaccines. Wkly. Epidemiol. Rec., v.84, p.405-420, 2009.

WORLD HEALTH ORGANIZATION. Hepatitis C - global prevalence (update). Wkly. Epidemiol. Rec., v.74, p.425$427,1999$.
XIMENES, R.A.A.; PEREIRA, L.M.B.; MERTELLI, C.M.T.; MERCHÁN-HAMANN, E.; STEIN, A.T.; FIGUEIREDO, G.M.; BRAGA, M.C.; MONTARROYOS, U.R.; BRASIL, L.M.; TURCHI, M.D.; FONSECA, J.C.F.; LIMA, M.L.C.; ALENCAR, L.C.A.; COSTA, M.; CORAL, G.; MOREIRA, R.C.; CARDOSO, M.R.A. Methodology of a nationwide cross-sectional survey of prevalence and epidemiological patterns of hepatitis A, B and C infection in Brazil. Cad. Saúde Pública, v.26, p.1693-1704, 2010.

ZANETTI, A.R.; MARIANO, A.; ROMANÒ, L.; D’AMELIO, R.; CHIRONNA, M.; COPPOLA, R.C.; CUCCIA, M.; MANGIONE, R.; MARRONE, F.; NEGRONE, F.S.; PARLATO, A.; ZAMPARO, E.; ZOTTI, C.; STROFFOLINI, T.; MELE, A. Long-term immunogenicity of hepatitis B vaccination and policy for booster: an Italian multicentre study. Lancet, v.366, p.1379-1384, 2005.

Received for publication on $14^{\text {th }}$ July 2011 Accepted for publication on $06^{\text {th }}$ March 2012 